Romantic
Potency 


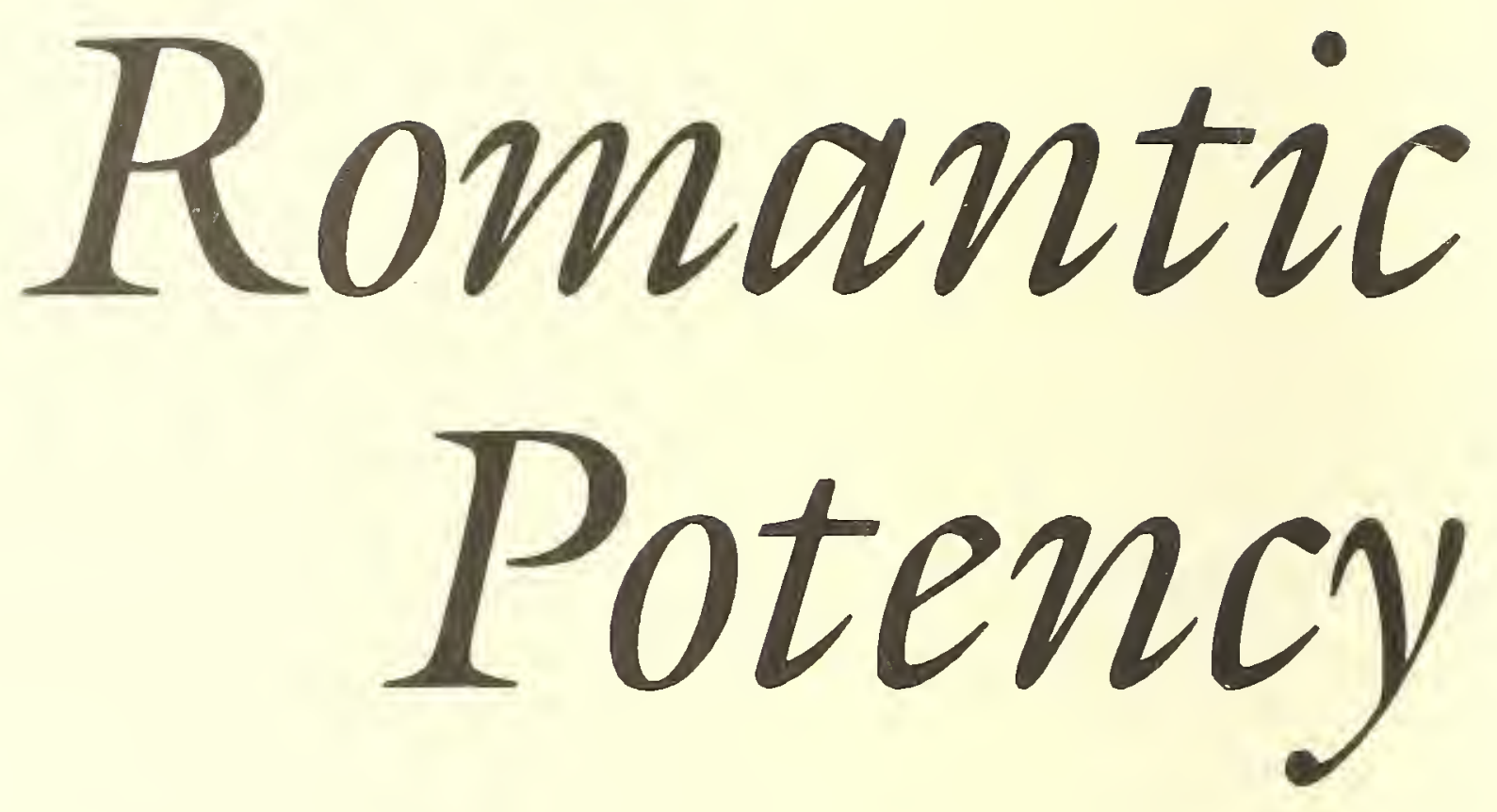

Cornell University Press - Ithaca and London 
THE PARADOX

OF DESIRE

\section{Laura Claridge}




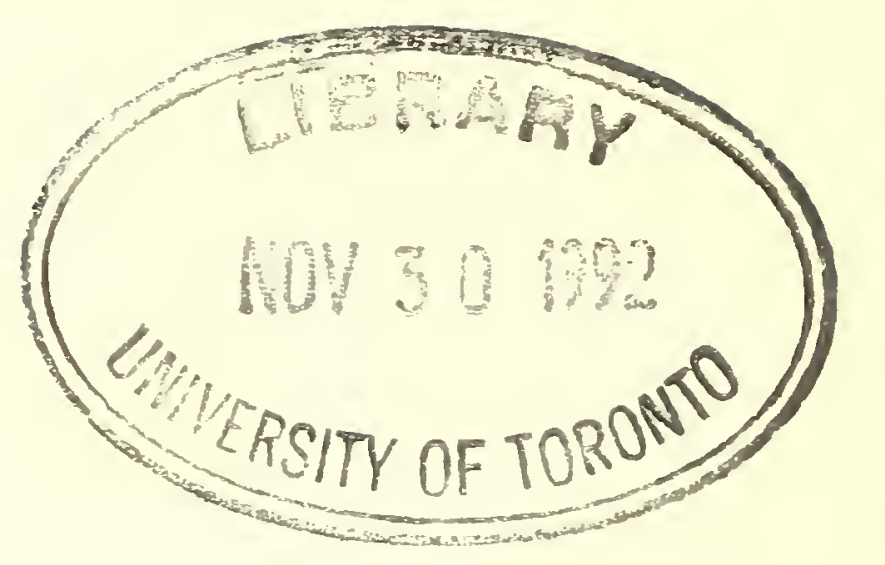

Copyright (C) I 992 by Cornell University

All rights reserved. Except for brief quotations in a review, this book, or parts thereof, must not be reproduced in any form without permission in writing from the publisher. For information, address Cornell University Press, I 24 Roberts Place, Ithaca, New York I 4850.

First published 1992 by Cornell University Press.

International Standard Book Number o-8014-2696-0 (cloth) International Standard Book Number o-8014-8016-7 (paper) Library of Congress Catalog Card Number 9I-55556

Printed in the United States of America

Librarians: Library of Congress cataloging information appears on the last page of the book.

( $)$ The paper in this book meets the minimum requirements of the American National Standard for Information Sciences-Permanence of Paper for Printed Library Materials, ANSI Z39.48-r984. 
for Jon

Some of us come on earth seeing,

Some of us come on earth seeing colors.

- Louise Nevelson 
